\title{
SKIV2L Gene
}

National Cancer Institute

\section{Source}

National Cancer Institute. SKIV2L Gene. NCI Thesaurus. Code C24813.

This gene plays a role in blocking the translation of poly(A)-deficient mRNAs. 